\title{
Circuit and Plasticity Defects in the Developing Somatosensory Cortex of Fmr1 Knock-Out Mice
}

\author{
Ingrid Bureau, ${ }^{1}$ Gordon M. G. Shepherd, ${ }^{1,2}$ and Karel Svoboda ${ }^{1,3}$ \\ ${ }^{1}$ Howard Hughes Medical Institute, Cold Spring Harbor Laboratory, Cold Spring Harbor, New York 11724, ${ }^{2}$ Department of Physiology, Northwestern \\ University, Chicago, Illinois 60611, and ${ }^{3}$ Howard Hughes Medical Institute, Janelia Farm Research Campus, Ashburn, Virginia 20147
}

\begin{abstract}
Silencing of the Fmrl gene causes fragile X syndrome. Although defects in synaptic plasticity in the cerebral cortex have been linked to cognitive impairments in Fmrl knock-out (ko) mice, the specific cortical circuits affected in the syndrome are unknown. Here, we investigated the development of excitatory projections in the barrel cortex of Fmr1 ko mice. In 2-week-old Fmr1 ko mice, a major ascending projection connecting layer 4 (L4) to L3 (L4 $\rightarrow \mathrm{L} 3$ ), was defective in multiple and independent ways: its strength was reduced, caused by a lower connection probability; the axonal arbors of L4 cells were spatially diffuse in L2/3; the L4 $\rightarrow$ L3 projection did not show experience-dependent plasticity. By 3 weeks, the strength of the $\mathrm{L} 4 \rightarrow \mathrm{L} 3$ projection was similar to that of wild type. Our data indicate that Fmr1 shapes sensory cortical circuits during a developmental critical period.
\end{abstract}

Key words: barrel; cortex; development; network; neuron; plasticity

\section{Introduction}

Fragile X syndrome is the most prevalent inherited form of mental retardation and is associated with learning disabilities, seizures, hyperactivity, and autism (O'Donnell and Warren, 2002). The syndrome is caused by the absence of functional fragile $\mathrm{X}$ mental retardation protein (FMRP) (Jin and Warren, 2000). FMRP contains multiple RNA binding domains (Ashley et al., 1993; Siomi et al., 1993), binds to polyribosomal complexes (Siomi et al., 1996; Feng et al., 1997; Darnell et al., 2005), and is thought to regulate protein synthesis (Brown et al., 2001; Greenough et al., 2001; Zhang et al., 2001; Todd et al., 2003).

The Fmrl knock-out (ko) mouse (Dutch-Belgian Fragile X Consortium, 1994) is an excellent model of fragile $\mathrm{X}$ syndrome. Fmrl ko mice have learning deficits (Dutch-Belgian Fragile X Consortium, 1994; Paradee et al., 1999; Peier et al., 2000), abnormal social behaviors (Spencer et al., 2005; Mineur et al., 2006), and audiogenic seizures (Musumeci et al., 2000; Chen and Toth, 2001; Yan et al., 2004). Neocortical and hippocampal neurons in Fmrl ko mice have denser and thinner dendritic spines, suggesting a defect in spine development or elimination (Comery et al., 1997; Irwin et al., 2001; Nimchinsky et al., 2001; McKinney et al., 2005; Antar et al., 2006; Grossman et al., 2006). Fmr1 ko mice also exhibit abnormal synaptic plasticity: long-term depression (LTD) of synaptic transmission is enhanced in the hippocampus (Huber et al., 2002) and the cerebellum (Koekkoek et al., 2005), whereas

\footnotetext{
Received May 25, 2007; accepted March 17, 2008.

This work was supported by National Institutes of Health, Howard Hughes Medical Institute, and FRAXA Research Foundation. We thank Mac Hooks for measuring the reversal potential of GABAergic conductances and Alla Karpova and Leopoldo Petreanu for a critical reading of this manuscript.

Correspondence should be addressed to Ingrid Bureau at her present address: Institut de Neurobiologie de la

Méditerranée, 163 route de Luminy, BP 13, 13273 Marseille, France. E-mail: ingrid.bureau@inmed.univ-mrs.fr. D0I:10.1523/JNEUROSCI.1076-08.2008

Copyright $\odot 2008$ Society for Neuroscience $\quad 0270-6474 / 08 / 285178-11 \$ 15.00 / 0$
}

long-term potentiation (LTP) is reduced in cortex (Li et al., 2002; Larson et al., 2005; Zhao et al., 2005; Desai et al., 2006; Wilson and Cox, 2007) and in the amygdala (Zhao et al., 2005).

To link the molecular and cellular phenotypes with the behavioral phenotypes, it will be necessary to understand the defects at the level of neural circuits in Fmr1 ko mice. To begin to address this issue, we investigated the experience-dependent development of intracortical circuitry in the mouse barrel cortex of Fmr1 ko mice. Barrel cortex circuits are organized in functional columns spanning multiple layers (L1-L6). Barrels in L4 receive sensory information from individual whiskers via thalamocortical projections (Bernardo and Woolsey, 1987). Barrels can be used as stable anatomical landmarks to identify individual columns in brain slices (Woolsey and Van der Loos, 1970; Finnerty et al., 1999). Most excitatory intracortical circuitry develops during the second postnatal week (Micheva and Beaulieu, 1996; Stern et al., 2001; Bender et al., 2003; Bureau et al., 2004). In particular, the major ascending projection in the barrel cortex, connecting L4 and L3 (L4 $\rightarrow$ L3), develops between postnatal day 8 (P8) and P15 (Bender et al., 2003; Bureau et al., 2004). Sensory deprivation by whisker trimming during the second week of life causes abnormal L2/3 receptive fields (Fox, 1992; Stern et al., 2001), depresses L4 $\rightarrow$ L2/3 synapses (Allen et al., 2003; Shepherd et al., 2003), and decreases L2/3 spine structural plasticity (Lendvai et al., 2000).

Here, we combined laser-scanning photostimulation (LSPS) mapping and reconstruction of axonal arbors to compare the development of excitatory projections impinging onto L2/3 neurons in wild-type and Fmrl ko mice. We found that specific circuits are defective in Fmrl ko mice. In particular, multiple features of the principal ascending $\mathrm{L} 4 \rightarrow \mathrm{L} 3$ projection, but not the $\mathrm{L} 5 \mathrm{~A} \rightarrow \mathrm{L} 3$ and $\mathrm{L} 5 \mathrm{~B} \rightarrow \mathrm{L} 3$ projections, show a major developmental delay. 


\section{Materials and Methods}

Brain slice preparation and electrophysiology. Male Fmr1 ko mice in a C57BL/6 background and male wild-type littermates were used in accordance with Cold Spring Harbor Laboratory institutional guidelines. Genotypes were determined post hoc by PCR analysis of DNA extracted from tail samples (Dutch-Belgian Fragile X Consortium, 1994). Deprived mice had their D-row whiskers trimmed to $\sim 1 \mathrm{~mm}$ every other day from P9 to P13-P15. Across-row barrel cortex slices (300 $\mu \mathrm{m}$ thick) were cut as described previously (Finnerty et al., 1999; Shepherd and Svoboda, 2005) in chilled cutting solution containing the following (in $\mathrm{mm}$ ): 110 choline chloride, $25 \mathrm{NaHCO}_{3}, 25$ D-glucose, 11.6 sodium ascorbate, $7 \mathrm{MgCl}_{2}, 3.1$ sodium pyruvate, $2.5 \mathrm{KCl}, 1.25 \mathrm{NaH}_{2} \mathrm{PO}_{4}$, and $0.5 \mathrm{CaCl}_{2}$. Slices were transferred to artificial CSF (ACSF) containing the following (in mM): $127 \mathrm{NaCl}, 25 \mathrm{NaHCO}_{3}, 25$ D-glucose, $2.5 \mathrm{KCl}, 1$ $\mathrm{MgCl}_{2}, 2 \mathrm{CaCl}_{2}$, and $1.25 \mathrm{NaH}_{2} \mathrm{PO}_{4}$, aerated with $95 \% \mathrm{O}_{2}$ and $5 \% \mathrm{CO}_{2}$, first at $34^{\circ} \mathrm{C}$ for $15 \mathrm{~min}$ and then at room temperature before use.

Neurons (40-105 $\mu \mathrm{m}$ deep in the slice; average, $71 \pm 1 \mu \mathrm{m} ; n=122)$ were visualized with infrared gradient contrast optics and patched using borosilicate electrodes $(4-6 \mathrm{M} \Omega)$. The intracellular solution contained the following (in $\mathrm{mm}$ ): $128 \mathrm{~K}$-methylsulfate, $4 \mathrm{MgCl}_{2}, 10 \mathrm{HEPES}, 1$ EGTA, $4 \mathrm{Na}_{2}$ ATP, $0.4 \mathrm{Na}_{2}$ GTP, $10 \mathrm{Na}$-phosphocreatine, 3 ascorbic acid, and 0.015 Alexa 594 (Invitrogen, Carlsbad, CA), pH 7.25 and 294 mOsm. Whole-cell recordings were made using a Multiclamp 700A (Molecular Devices, Sunnyvale, CA) amplifier. Cells were identified based on their laminar and columnar positions using Alexa 594 fluorescence. In the P13-P15 wild-type mice, L3 pyramidal cells had the following membrane properties: membrane capacitance $\left(C_{\mathrm{m}}\right), 136 \pm 3 \mathrm{pF}$; input resistance $\left(R_{\mathrm{i}}\right), 278 \pm 10 \mathrm{M} \Omega$; access resistance $\left(R_{\mathrm{s}}\right), 28 \pm 1 \mathrm{M} \Omega(n=49) ; \mathrm{L} 3$ cells in the P13-P15 Fmr1 ko: $C_{\mathrm{m}}, 139 \pm 5 \mathrm{pF} ; R_{\mathrm{i}}, 264 \pm 13 \mathrm{M} \Omega ; R_{\mathrm{s}}, 25 \pm 1 \mathrm{M} \Omega$ $(n=42)$; L3 cells in the P19-P22 wild-type mice: $C_{\mathrm{m}}, 151 \pm 11 \mathrm{pF} ; R_{\mathrm{i}}$, $148 \pm 9 \mathrm{M} \Omega ; R_{\mathrm{s}}, 30 \pm 1 \mathrm{M} \Omega(n=18) ; \mathrm{L} 3$ cells in the P19-P22 Fmrl ko mice: $C_{\mathrm{m}}, 175 \pm 11 \mathrm{pF} ; R_{\mathrm{i}}, 171 \pm 19 \mathrm{M} \Omega ; R_{\mathrm{s}}, 29 \pm 2 \mathrm{M} \Omega(n=13)$. EPSCs were measured in whole-cell configuration at $-70 \mathrm{mV}$, near the reversal potential of GABAergic conductances $(-68.3 \pm 0.6 \mathrm{mV}$; mean $\pm \mathrm{SD}$; $n=3$ ). Action potentials (APs) were recorded in loose-seal, cell-attached configuration. Custom software for instrument control and acquisition was written in Matlab (Mathworks, Natick, MA).

LSPS by glutamate uncaging. LSPS was performed as described by Shepherd and Svoboda (2005). Recirculating ACSF solution contained the following (in mM): $0.37 \mathrm{NI}$ (nitroindolinyl)-caged glutamate (Canepari et al., 2001) (Sigma/RBI, Natick, MA), 0.005 CPP [( \pm )-3-(2carboxypiperazin-4-yl)propyl-1-phosphonic acid], $4 \mathrm{CaCl}_{2}$, and 4 $\mathrm{MgCl}_{2}$. Once whole-cell recording was established, focal photolysis of caged glutamate was accomplished with a $1 \mathrm{~ms}$ pulse of a pulsed UV laser (wavelength, $355 \mathrm{~nm}$; repetition rate, $100 \mathrm{kHz}$; DPSS Lasers, San Jose, CA) consisting of 100 pulses. Laser power was $20 \mathrm{~mW}$ at the specimen for LSPS mapping.

The standard stimulus pattern for LSPS mapping consisted of 256 positions on a $16 \times 16$ grid. Spacing was set to $75 \mu \mathrm{m}$ between adjacent rows and columns, giving a $1.125 \times 1.125 \mathrm{~mm}$ mapping region. The slice was oriented so that the pia was on the top and the barrels A to E were aligned horizontally from left to right. The horizontal midline of the uncaging grid was on the top of L4/L5A boundary. The vertical midline was centered on the barrel C or D or on the septum between $\mathrm{C}$ and $\mathrm{D}$ barrels. UV stimuli were presented once every $1 \mathrm{~s}$. The laser was moved in a spatial pattern designed to avoid consecutive glutamate uncaging over neighboring pixel sites (Shepherd et al., 2003). Traces consisted of $100 \mathrm{~ms}$ of baseline before the stimulus, a $500 \mathrm{~ms}$ response interval, and a test pulse for measuring electrophysiological parameters.

LSPS was also used to quantify the generation of spikes in neurons. Excitation profiles of cortical cells were recorded in loose-seal configuration while uncaging glutamate over a smaller grid (centered on the soma, $8 \times 8$ grid, $50 \mu \mathrm{m}$ spacing, $350 \times 350 \mu \mathrm{m}$ ).

Analysis of LSPS data. Synaptic input maps for individual neurons were constructed by computing the mean current amplitude calculated in a $100 \mathrm{~ms}$ time window $7 \mathrm{~ms}$ after the UV stimulus for each location of photostimulation. Typically two to four maps were obtained per cell and averaged (see Fig. $1 \mathrm{~A}$ ). Synaptic responses were stable across repetitions: the mean response evoked with uncaging over L4 changed by a factor of $0.99 \pm 0.05$ in wild-type mice $(n=25)$ and $1.14 \pm 0.10$ in Fmrl ko mice $(n=17)$ from the first to last maps [not significant (NS)]. Therefore LSPS-mapping did not induce synaptic plasticity. Averaged single-cell maps were used to compute group-averaged maps (see Fig. 1C). Interpolation was performed on averaged synaptic input maps for display purposes.

The mean distance of L4 synaptic inputs feeding into L3 was calculated as follows: $\Sigma$ (synaptic input $\times$ absolute lateral distance from the center of barrel) $/ \Sigma$ (synaptic input).

Traces of loose-seal recordings were analyzed for APs. A spatial profile of excitability (excitation profile) was generated by plotting the number of APs elicited at each uncaging site in a $100 \mathrm{~ms}$ time window immediately after the stimulus (see Fig. $2 E$ ). L3 pyramidal cells fired $3.8 \pm 0.5$ APs in the wild-type mice $(n=11)$ and $4.2 \pm 0.9$ APs in the Fmrl ko mice $(n=5)$. L5A pyramidal cells fired $3.1 \pm 0.3 \mathrm{APs}$ in the wild-type mice $(n=12)$ and $3.9 \pm 0.7$ APs in the Fmrl ko mice $(n=10)$. The mean distance from the soma where APs were evoked was calculated as follows: $\Sigma($ APs $\times$ absolute distance from the soma $) / \Sigma(\mathrm{APs})$. The mean distance for evoking APs in L3 pyramidal cells was $39 \pm 4 \mu \mathrm{m}$ in wild-type mice and $31 \pm 3 \mu \mathrm{m}$ in Fmrl ko mice (NS). The mean distance for evoking APs in L5A pyramidal cells was $43 \pm 4 \mu \mathrm{m}$ in wild-type mice and $35 \pm 2 \mu \mathrm{m}$ in Fmrl ko mice (NS).

Pyramidal cells $(n=21)$ and fast-spiking nonpyramidal (presumably GABAergic) interneurons $(n=13)$ in L3 did not spike when glutamate was uncaged over L4, indicating that disynaptic inhibition and disynaptic excitation did not contribute to the synaptic input originating from barrels. Under our conditions, LSPS excites neurons in the top $100 \mu \mathrm{m}$ of the brain slice (Shepherd and Svoboda, 2005).

Minimal stimulations. A LSPS input map was generated on a $8 \times 8$ grid, $50 \mu \mathrm{m}$ spacing, positioned over the $\mathrm{C}$ or $\mathrm{D}$ barrel. Glutamate was then uncaged 20-70 times every $15 \mathrm{~s}$ at a site where one of the largest responses was detected in the input map. The laser power was lowered until one or two unitary postsynaptic currents (UPSCs) of constant amplitude were seen repeatedly with detectable failure rates (5-45\%). These failures were attributable to failures in evoking APs in L4 cells. UPSCs arising within $300 \mathrm{~ms}$ after the flash stimulus were detected using the smoothed first derivative of the electrophysiological traces. A threshold (0.15-0.28) was set for each experiment to maximize the detection of small events. Amplitudes of 14-25 first UPSCs were averaged per $\mathrm{L} 4 \rightarrow \mathrm{L} 3$ connection. Their amplitudes ranged from 3 to $85 \mathrm{pA}$ (average, $17 \mathrm{pA})$.

Reconstructions of axonal and dendritic arbors. In a parallel set of experiments, layer 4 cells located in barrels and L3 cells located above barrels were recorded with pipettes containing $2 \mathrm{mg} / \mathrm{ml}$ biocytin (in the intracellular solution noted above). Cell bodies were distributed evenly within the $\mathrm{C}$ and $\mathrm{D}$ columns in nondeprived mice. L4 cells filled in deprived mice were all located in D barrels. L3 neurons were pyramidal cells and L4 neurons were stellate cells. Cells were 50-110 $\mu \mathrm{m}$ deep (average, $76 \pm 1 \mu \mathrm{m} ; n=102$ ). After 5 min of whole-cell configuration, the pipette was gently pulled out to form an outside-out patch. After allowing for diffusion of the biocytin $(2 \mathrm{~h})$ at room temperature, slices were fixed in $4 \%$ paraformaldehyde in sodium phosphate buffer for $48 \mathrm{~h}$. Subsequently, the slices were rinsed in sodium phosphate buffer and endogenous peroxidases were quenched with $1 \% \mathrm{H}_{2} \mathrm{O}_{2}$ for $30 \mathrm{~min}$. Slices were processed for avidin-biotin-peroxidase reaction (Vector Laboratories, Burlingame, CA) in Tris-buffered solution and mounted in dimethylsulfoxide. Axons arose from a single process emanating from the base of the cell body, did not taper, and had en passant boutons. Dendrites were studded with numerous dendritic spines. The axonal and dendritic arbors were reconstructed in three dimensions using a $40 \times$, numerical aperture (NA) 1.15 objective (Olympus, Tokyo, Japan) and Neurolucida software (MicroBrightField, Williston, VT). Data were imported into Matlab for additional analysis. Axons and dendrites were analyzed in three dimensions and the data were collapsed into two dimensions to generate a map of the axonal or dendritic length density [length per $(50 \mu \mathrm{m})^{2}$ ]. For display only, interpolation was performed on group average images. Mean horizontal distance of axons was calculated 
A

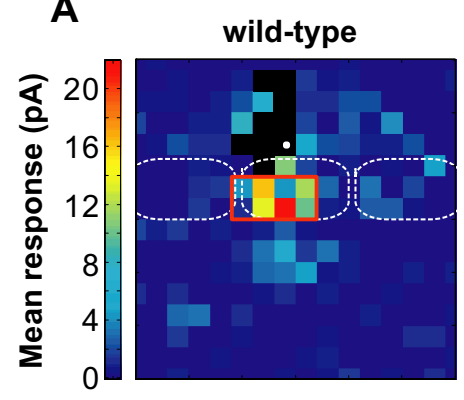

B
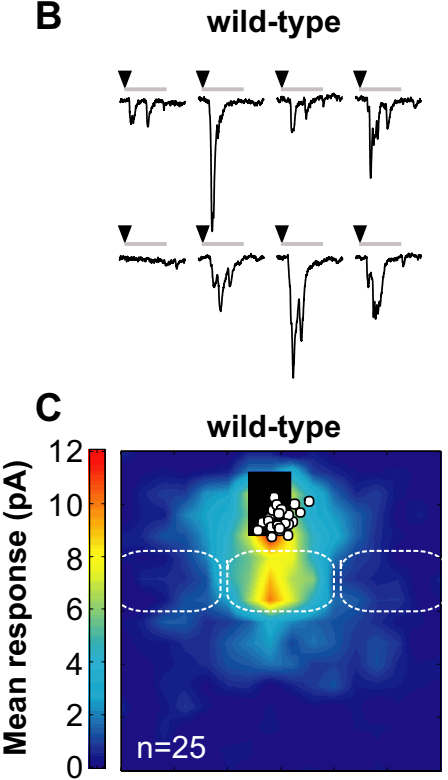

Fmr1 ko

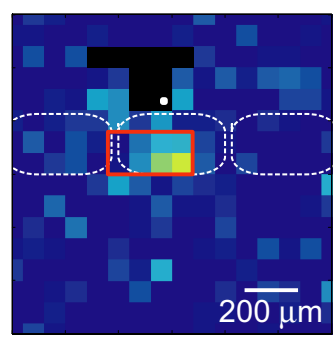

Fmr1 ko

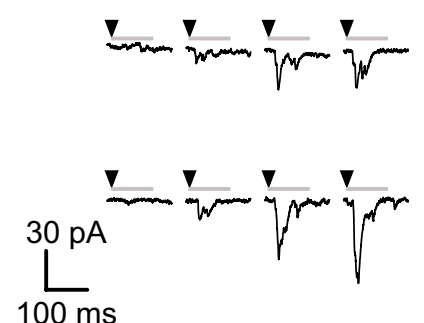

$100 \mathrm{~ms}$
D

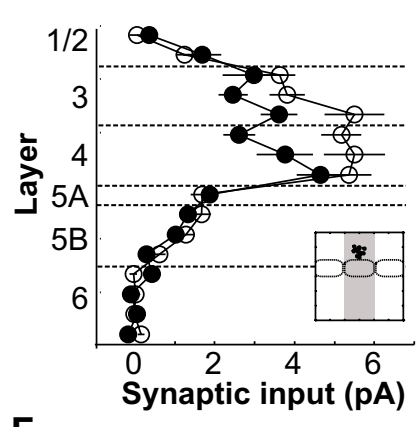

F

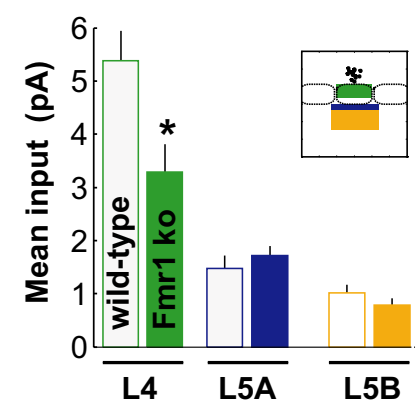

E

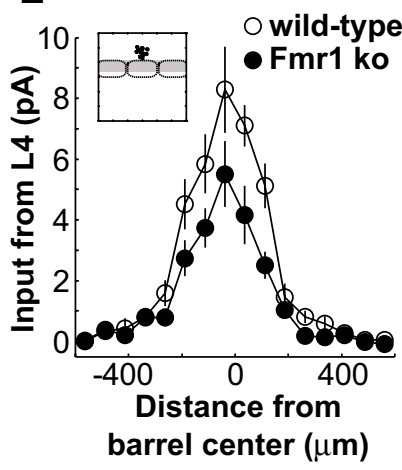

Figure 1. Laser-scanning photostimulation by glutamate uncaging to map circuitry in brain slices from wild-type and $F m r 1$ knock-out mice. $A$, Examples of synaptic input maps for individual L3 cells from a wild-type (left) and a Fmr $1 \mathrm{ko}$ (right) mouse. The pixel values encode the mean amplitudes of EPSCs measured over $100 \mathrm{~ms}$ after the stimulus (see $\boldsymbol{B}$ ). The black pixels are sites where glutamate uncaging evoked direct responses in the recorded cells that polluted synaptic responses. The white circles mark the cell body position of the recorded cells. The dashed lines indicate three barrels. The red box in $L 4$ corresponds to the traces shown in $\boldsymbol{B}$. B. Examples of EPSCs evoked by glutamate uncaging in $L 4$ (corresponding to red box in $\boldsymbol{A}$ ). The arrowheads indicate time of the photostimulus (duration, $1 \mathrm{~ms}$ ). The horizontal lines indicate time windows used for the analysis (duration, $100 \mathrm{~ms}$ ). C, Synaptic input maps from wild-type (left) and $F \mathrm{mr} 1 \mathrm{ko}$ (right) mice averaged over L3 cells. D, Vertical profile (75 $\mu \mathrm{m}$ bins) of synaptic inputs in the wild-type (open symbol) and Fmr $1 \mathrm{ko}$ (solid symbol) mice. Inset, The gray bar indicates the region of analysis. $\boldsymbol{E}$, Horizontal profile (75 $\mu \mathrm{m}$ bins) of $L 4$ inputs in the wild-type (open symbol) and Fmr $1 \mathrm{ko}$ (solid symbol) mice. Inset, The gray bar indicates the region of analysis. Note that we limited analysis to the top two-thirds of $L 4$ because previous data indicates that $L 5 A$ neurons are excited on photostimulation in the bottom one-third of $L 4$ (Bureau et al., 2006). $F$, Summary of interlaminar connectivity in wild-type (open bars) and Fmr1 ko (solid bars) mice. The regions of analysis for L4 (green), L5A (blue), and L5B (orange) inputs are shown in the inset. The asterisk indicates significant difference $(p<0.05)$. Error bars indicate SEM.

with the following equation: $\Sigma$ (axonal length density $\times$ horizontal distance from soma) $/ \Sigma$ (axonal length density).

Cell counting. Mice (P14) were anesthetized with a peritoneal injection of ketamine/xylazine mixture before being perfused transcardially with $4 \%$ paraformaldehyde. The brain was sectioned $(60 \mu \mathrm{m})$ with the same procedure as for the LSPS experiments. Sections were rinsed in $10 \%$ goat serum complemented with $0.3 \%$ Triton X-100 and treated with the primary mouse clone NeuN antibody (Invitrogen) and with the biotin-SPAffiniPure $\mathrm{F}\left(\mathrm{ab}^{\prime}\right)_{2}$ fragment as secondary antibody (Jackson ImmunoResearch Laboratories, West Grove, PA). Slices were then processed for avidin-biotin-peroxidase reaction (Vector Laboratories) in Trisbuffered solution and mounted in dimethylsulfoxide. The method of dissector was used to measure the neuron density in L4. The position of nuclei located inside a rectangle that covered a single barrel (width, 300$400 \mu \mathrm{m}$; height, $200 \mu \mathrm{m}$ ) was marked under a $40 \times$, NA 1.15 objective (Olympus) with Neurolucida software (MicroBrightField). Nuclei located on the limits of the rectangle were only counted along two sides of its width and height. The neuronal density was homogeneous across L4 because the A-E barrels were cut parallel to their larger walls and orthogonal to their hollow-wall axis.
All data are presented as an average \pm SEM. The $p$ values are for Mann-Whitney test.

\section{Results}

To analyze circuits in wild-type and Fmr1 ko mice, we mapped the functional excitatory projections impinging onto $\mathrm{L} 2 / 3$ neurons in brain slices. Brain slices were prepared from 2-week-old (P13-P15) mice and contained multiple barrel columns (rows A to E) (Finnerty et al., 1999; Shepherd and Svoboda, 2005). This age corresponds to a rapid phase of experience-dependent development of intracortical circuitry (Stern et al., 2001; Bender et al., 2003; Shepherd et al., 2003; Bureau et al., 2004). The barrels and septa were clearly visible in L4, in both wild-type and Fmr1 ko mice.

We used LSPS to survey excitatory circuits (Fig. 1). Whole-cell recordings were made from $\mathrm{L} 3$ pyramidal cells located above barrels (Bureau et al., 2006). EPSCs were isolated by holding the membrane potential near the reversal potential for inhibitory 
A

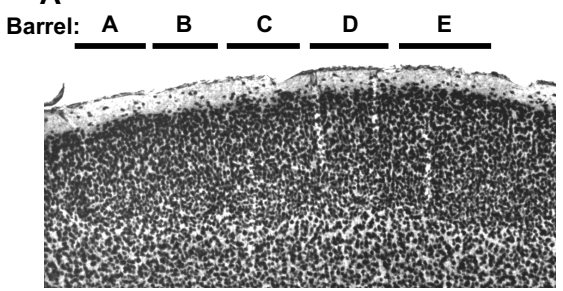

B

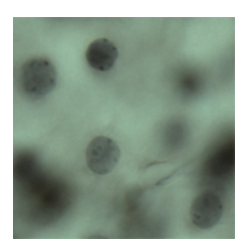

D

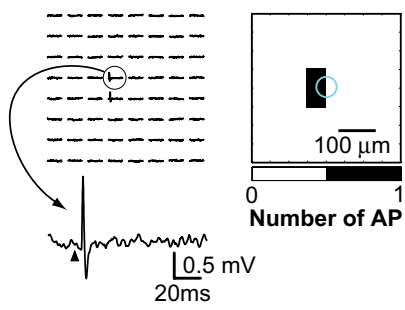

E

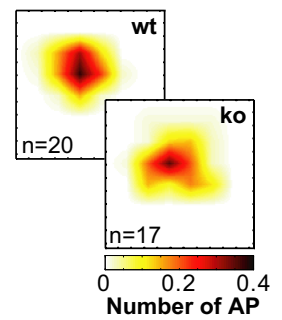

C

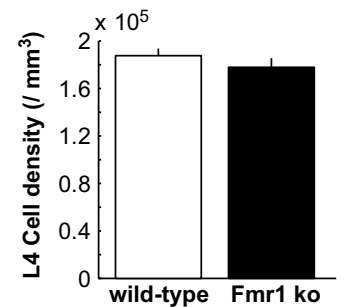

F

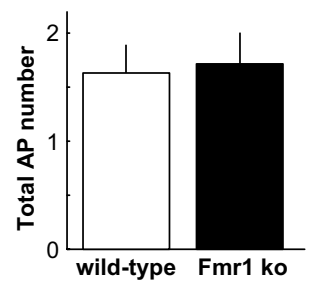

to the sum of synaptic input arising from the optical excitation volume $\left(V_{\text {exc }}\right) . Q_{x y}$ is thus proportional to the density of neurons $\left(\rho_{\text {cell }}\right), V_{\text {exc }}$, the average number of APs fired per stimulated neuron $\left(N_{\mathrm{AP}}\right)$, and the synaptic strength per action potential averaged over all photostimulated neurons (connected or not) $\left(I_{\text {con }}\right)$ (Shepherd et al., 2005) as follows:

$$
Q_{x y}=\left(\rho_{\text {cell }} \times V_{\text {exc }} \times N_{\mathrm{AP}}\right) \times I_{\text {con }},
$$

The brackets delineate parameters unrelated to synapses, whereas $I_{\text {con }}$ describes the synaptic projection. $I_{\text {con }}$ is given by the following:

$$
I_{\text {con }}=P_{\text {con }} \times i_{\text {uni. }}
$$

$P_{\text {con }}$ is the average connection probability per unit density of the stimulated neurons. $i_{\text {uni }}$ is the average connection strength between a pair of connected neurons and is equal to the product of the quantal response, the number of synapses for each pair, and the release probability per synapse.

currents $(-70 \mathrm{mV})$ (see Materials and Methods) (Fig. 1B). EPSCs were evoked by glutamate uncaging on a $16 \times 16$ pixel grid (pixel spacing, $75 \mu \mathrm{m}$ ) in the barrel cortex (Fig. 1A) (see Materials and Methods) (Shepherd and Svoboda, 2005). Presynaptic neurons at each stimulation site in the slice are selectively excited close to their cell bodies (while avoiding axons of passage), providing sublaminar and subcolumnar resolution. Each response to photostimulation was quantified as the mean synaptic current amplitude in a $100 \mathrm{~ms}$ window, starting $7 \mathrm{~ms}$ after the UV stimulus (Fig. $1 B$ ). For each recorded L3 cell, we generated a synaptic input map by plotting the spatial distribution of the synaptic responses (Fig. 1A). The input map represents the spatial distribution of excitatory input to the recorded neuron with $\sim 50 \mu \mathrm{m}$ resolution.

\section{Fmr1 ko mice have weaker $\mathrm{L} 4 \rightarrow \mathrm{L} 3$ projections}

L3 cells received strong input from other L3 cells and L4 barrel cells immediately below (Bureau et al., 2006) (Fig. 1A,C). The $\mathrm{L} 4 \rightarrow \mathrm{L} 3$ projection was $40 \%$ weaker in the Fmr1 ko compared with wild-type mice (Fig. 1C,D) (mean synaptic currents; wild type, $5.4 \pm 0.6 \mathrm{pA}, n=25$; Fmr1 ko, $3.3 \pm 0.5 \mathrm{pA}, n=17$; $p<$ $0.05)$, whereas the spatial distribution of input from L4 along the horizontal axis was not different (mean lateral distance; wild type, $151 \pm 6 \mu \mathrm{m}$; Fmrl ko, $166 \pm 9 \mu \mathrm{m}$; NS) (Fig. $1 E$ ). Note that we cannot exclude a small contribution from the L3 $\rightarrow$ L3 projections for synaptic input originating from the upper part of barrels. The L4 projections impinging onto L3 cells located above septa were not different in wild-type and Fmrl ko mice (supplemental Fig. 1, available at www.jneurosci.org as supplemental material). Similarly, the $\mathrm{L} 5 \mathrm{~A} \rightarrow \mathrm{L} 3$ and $\mathrm{L} 5 \mathrm{~B} \rightarrow \mathrm{L} 3$ projections in the barrel column did not differ in the two genotypes (Fig. $1 F$ ).

These data suggest a reduction in the strength of the major ascending L4 $\rightarrow$ L3 excitatory projection in Fmrl ko mice. However, in addition to synaptic factors, multiple other mechanisms could contribute to the observed differences in the input maps. Each pixel (position, $x, y)$ in the synaptic input map $\left(Q_{x y}\right)$ is equal

To distinguish between synaptic and nonsynaptic factors of the circuit perturbation in the Fmr1 ko mice, we first tested for possible changes in nonsynaptic parameters (Eq. 1). To estimate $\rho_{\text {cell }}$, we labeled neurons with the nuclear marker NeuN and measured the density of NeuN-positive nuclei in L4 barrels (Mullen et al., 1992) (Fig. 2A,B). Cell densities were indistinguishable in the wild-type and Fmrl ko mice (wild type, $1.87 \pm 0.06 \times 10^{5} / \mathrm{mm}^{3}$, $n=10$; Fmrl ko, $1.78 \pm 0.07 \times 10^{5} / \mathrm{mm}^{3}, n=13$; NS) (Fig. 2C). To measure $V_{\text {exc }}$ and $N_{\mathrm{AP}}$, we mapped excitation profiles (Shepherd and Svoboda, 2005), corresponding to the number of action potentials triggered as a function of distance between the recorded cell and the uncaging beam. L4 cells fired one to five APs when glutamate was uncaged in the vicinity of their somata (Fig. 2D). Photoexcitability was similar in the wild-type and Fmrl ko mice (Fig. $2 E, F$ ) (wild type, $1.6 \pm 0.3 \mathrm{APs}, n=20$; Fmr 1 ko, $1.7 \pm$ 0.3 APs, $n=17$; NS) measured at comparable depths in the brain slice (wild type: depth, $56 \pm 3 \mu \mathrm{m}$; Fmrl ko: depth, $55 \pm 3 \mu \mathrm{m}$; NS). The spatial distributions of action potentials evoked by photostimulation were identical (wild type, $44 \pm 6 \mu \mathrm{m}$; Fmr1 ko, $43 \pm 4 \mu \mathrm{m}$; NS). Similar results were found for L3 and L5A (see Materials and Methods). Thus, none of the nonsynaptic parameters shaping synaptic input maps is perturbed in the Fmrl ko mice. Our data therefore confirm that the difference in synaptic input maps between wild-type and Fmrl ko mice is attributable to a reduction in the strength of the major ascending $\mathrm{L} 4 \rightarrow \mathrm{L} 3$ excitatory projection $\left(I_{\text {con }}\right)$ (Eq. 1).

\section{Decreased connection probability between L4 and L3 cells in Fmr1 ko mice}

We next studied the mechanisms underlying the weaker L4 $\rightarrow$ L3 projection in the Fmrl ko mice. The defect could be either attributable to a decreased connection probability between L4 and L3 cells $\left(P_{\text {con }}\right)$, or attributable to weaker average synaptic strength between connected pairs of neurons $\left(i_{\text {uni }}\right)$ (Eq. 2). To distinguish between these possibilities, we measured $i_{\text {uni }}$ using a LSPS-based minimal stimulation method. For each cell, we first generated a 
synaptic input map (Fig. $1 A$ ). We then uncaged glutamate repetitively at a single site $(0.067 \mathrm{~Hz})$ in L4 (corresponding to a pixel with a robust response). The laser power was decreased (from 20 to $8-17 \mathrm{~mW}$ ) until each stimulus evoked one or two clearly separable EPSCs or response failures (see Materials and Methods) (supplemental Fig. 2, available at www.jneurosci.org as supplemental material). Under these conditions, each EPSC corresponded to the stimulation of a single presynaptic cell firing one AP. The failures were explained by unsuccessful presynaptic stimulation rather than neurotransmitter release, consistent with multiple synapses between connected L4 $\rightarrow$ L3 neuron pairs (Feldmeyer et al., 2002; Silver et al., 2003). UPSCs were isolated from spontaneous synaptic events and clustered based on their amplitude and latency (Fig. $3 A-C)$. One to two clusters of UPSCs were detected for each cell (Fig. $3 A$ ). The amplitudes of UPSCs are a measure of $i_{\text {uni }}$.

The amplitude of UPSCs for individual L4 $\rightarrow$ L3 connections was similar in wildtype and Fmr1 ko mice (wild type, $20.7 \pm$ $2.5 \mathrm{pA}, n=19$; Fmrl ko, $19.6 \pm 3.0 \mathrm{pA}, n=$ 15; NS) (Fig. 3D). This indicates that the lack of FMRP did not affect $i_{\text {uni }}$. The defect in the $\mathrm{L} 4 \rightarrow \mathrm{L} 3$ projection is therefore likely attributable to a reduced connection probability $\left(P_{\text {con }}\right)$.

\section{Fmr1 ko mice have diffuse $\mathrm{L} 4 \rightarrow \mathrm{L} 2 / 3$ axonal arbors}

Connection probability between two neurons depends on the extent of the overlap between axonal and dendritic arbors. The difference in $P_{\text {con }}$ could thus be attributable to defects in the axonal arbors ascending from L4 into L2/3 or dendritic arbors of L2/3 cells. To test for this possibility, we filled individual L4 cells in barrels C or D with biocytin and reconstructed their axonal arborization in three dimensions (Fig. $4 A, B$ ). The axonal density was quantified on a pixel grid (spacing, $50 \mu \mathrm{m}$ ) in two-dimensional projections (Fig. $4 A-D$ ). The total axonal length in $\mathrm{L} 2 / 3$ was similar in wildtype and Fmrl ko mice (wild type, $4.8 \pm 0.6 \mathrm{~mm}, n=14 ;$ Fmrl ko, $5.3 \pm 0.9 \mathrm{~mm}, n=11$; NS), ruling out the hypothesis that a decrease in axon growth accounted for the reduced connection probability between L4 and L3 cells.

To quantify the spatial distribution of L4 axons in L2/3, we measured the axonal length density in $\mathrm{L} 2 / 3$ as a function of lateral distance from the L4 cell somata (Fig. 4 E). In the Fmr1 ko mice, the axonal length density was lower by a factor of 1.7 immediately above the $\mathrm{L} 4$ cell somata (lateral distance, $<50 \mu \mathrm{m}$ on either side of the L4 somata) but greater by a factor of 1.9 at a larger lateral distance $(200 \mu \mathrm{m})$. As a result, axons in Fmrl ko mice were at a larger mean lateral distance from the cell somata (mean distance, wild type, $103 \pm 8 \mu \mathrm{m}$; Fmrl ko, $154 \pm 14 \mu \mathrm{m} ; p<0.005$ ). Therefore, the spatial distribution of L4 axons in L2/3 was spatially more diffuse in the Fmrl ko mice compared with wild-type mice. In contrast, the dendrites of L3 pyramidal cells were indis(gray) and Fmr1 ko (black) mice.
B

C
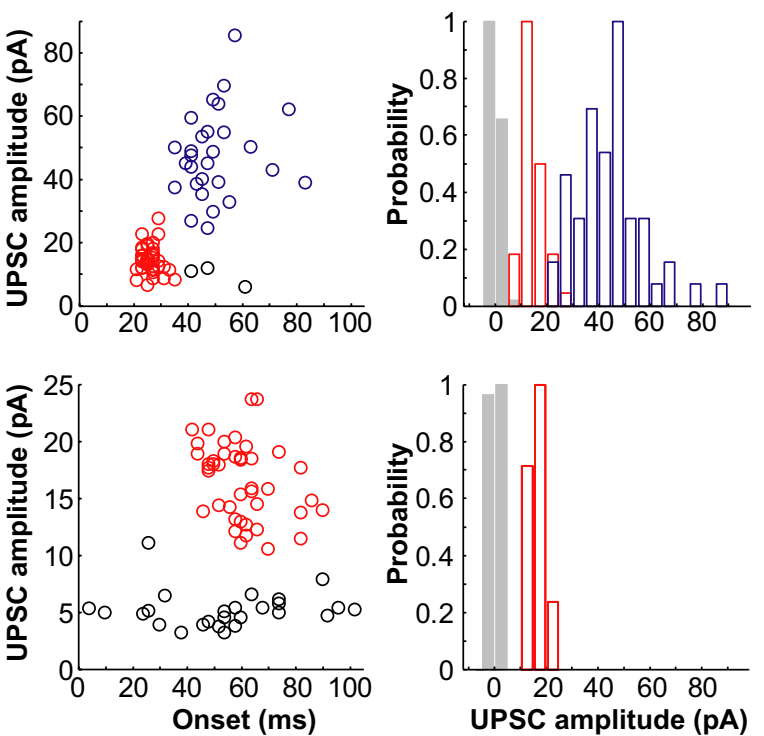

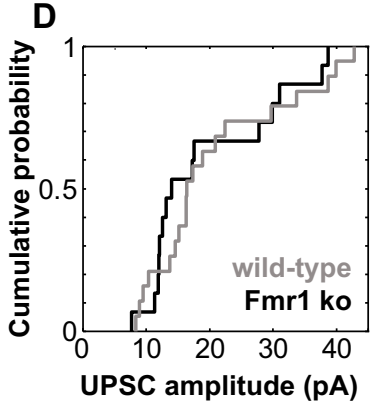

Figure 3. Individuals $L 4 / L 3$ connections have normal synaptic strength in the $F m r 1$ ko. $A$, Example of $L 3$ responses evoked by minimal photostimulations in L4 in a wild-type (top) and Fmr 1 ko (bottom) animal. The vertical dashed line indicates time of the photostimulus. The arrowheads indicate UPSCs evoked by the stimulation of distinct presynaptic $L 4$ cells (one color per presynSpontaneous EPSCs (black) had different latencies and/or amplitudes than clusters of UPSCs. The cells are the same as in $\boldsymbol{A}$. $\boldsymbol{C}$, amplitude is shown in gray. The cells are the same as in $\boldsymbol{A}$. $\boldsymbol{D}$, Cumulative distribution of UPSC mean amplitudes in wild-type

tinguishable in the two genotypes (supplemental Fig. $3 A, B$, available at www.jneurosci.org as supplemental material).

We next quantified the impact of spatially diffuse axonal arbors on the strength of the L4 $\rightarrow \mathrm{L} 3$ projection. Assuming that functional strength is predicted by the overlap of L3 dendrites and L4 axons alone, we computed the expected strength of the L4 $\rightarrow$ L3 projection based on neurogeometry (Lubke et al., 2003; Shepherd et al., 2005). These calculations predict only a negligible $(\sim 3 \%)$ reduction in the strength of these projections (supplemental Fig. 3C-G, available at www.jneurosci. org as supplemental material). We conclude that the defect in axonal structure by itself cannot account for the weaker L4 inputs to L3 cells.

\section{Lack of experience-dependent plasticity of the $\mathrm{L} 4 \rightarrow \mathrm{L} 3$ projection in Fmrl ko mice}

Sensory deprivation by whisker trimming in rats weakens the $\mathrm{L} 4 \rightarrow \mathrm{L} 2 / 3$ projection by $\sim 47 \%$ (Allen et al., 2003; Shepherd et al., 2003), resembling the circuit phenotype in Fmr1 ko mice (Fig. $1 C)$. To investigate possible interactions between the effects of 
A

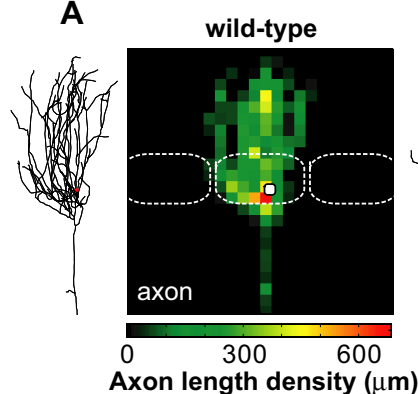

C

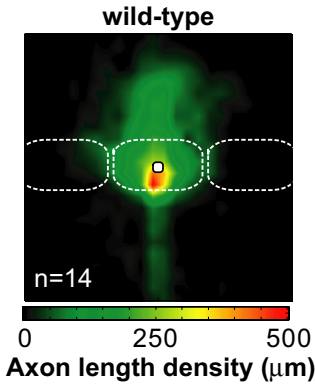

E

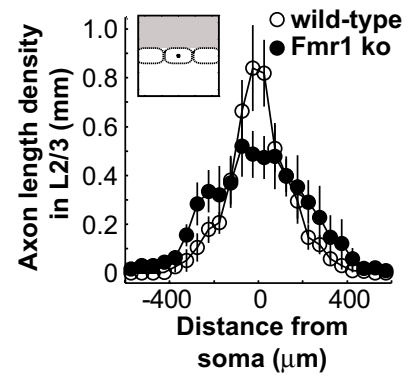

Figure 4. L4 cell axonal arbors in L2/3 are spatially diffuse in Fmr 1 ko mice. A, A L4 cell axonal arbor (left; soma shown in red) from a wild-type animal and the spatial distribution of the axonal length density for the same cell (right). The pixel values encode the axonal length in a pixel of $50 \times 50 \mu \mathrm{m}^{2}$ of the arbor reconstruction projected in two dimensions. $\boldsymbol{B}$, Same as in $\boldsymbol{A}$ for a Fmr 1 ko. C, Average distribution of the axonal length density for $L 4$ cells from wild-type mice. The $L 4$ cell arbors were aligned by soma position (white circle). D, Same as in C for Fmr 1 ko mice. $\boldsymbol{E}$, Horizontal profile ( $50 \mu \mathrm{m}$ bins) of $L 4$ cell axonal length density in $L 2 / 3$. The region of analysis is shown in inset (shaded area). Error bars indicate SEM.

sensory deprivation and absence of FMRP, we analyzed the effects of clipping the whisker D-row for 4-6 d. Similar to previous work in the rat, in the wild-type mice (P13-P15), whisker trimming decreased the strength (to $60 \%$ ) of the $\mathrm{L} 4 \rightarrow \mathrm{L} 3$ projection in the deprived column (Fig. 5A-C) (L4 control, $5.4 \pm 0.6 \mathrm{pA} ; \mathrm{L} 4$ deprived, $3.4 \pm 0.5 \mathrm{pA} ; p<0.05)$. In addition, the strength of the $\mathrm{L} 5 \mathrm{~A} \rightarrow \mathrm{L} 3$ projection increased (to $210 \%$ ) (Fig. $5 A, B, D$ ) (L5A control, $1.7 \pm 0.3 \mathrm{pA}$; L5A deprived, $3.6 \pm 0.5 \mathrm{pA} ; p<0.005)$. To disambiguate input to L3 neurons from L4 and L5A, we excluded from our analysis the lower one-third of L4 (Bureau et al., 2006). In Fmrl ko mice (P13-P15), experience-dependent depression of the $\mathrm{L} 4 \rightarrow \mathrm{L} 3$ projection was not seen (Fmrl ko L4 control, $3.3 \pm$ $0.5 \mathrm{pA}$; deprived, $3.5 \pm 0.2 \mathrm{pA}$; NS) (Fig. $5 A-C$ ), whereas potentiation of the $\mathrm{L} 5 \mathrm{~A} \rightarrow \mathrm{L} 3$ projection was maintained (Fmr1 ko L5A control, $2.0 \pm 0.3 \mathrm{pA}$; deprived, $4.2 \pm 0.7 \mathrm{pA} ; p<0.05)$ but with a different spatial organization (Fig. $5 A, B, D$ ). L5A $\rightarrow$ L3 potentiation was limited to the projections originating from the center of the deprived column in Fmrl ko mice (Fig. 5D). Therefore, Fmr1 $k o$ mice show a defect in experience-dependent plasticity in specific synaptic projections.
Normal experience-dependent plasticity of L4 $\rightarrow$ L3 synapses in Fmrl ko mice

Do shared synaptic mechanisms underlie the reduced strength of the $\mathrm{L} 4 \rightarrow \mathrm{L} 3$ projections in deprived wild-type mice and Fmr1 ko mice? To address this question, we analyzed the strength of unitary connections using minimal photostimulation in deprived wild-type and Fmr1 ko mice (Fig. 6A-C). The mean amplitude of UPSCs evoked by stimulating deprived barrels was $12.9 \pm 2.2 \mathrm{pA}$ in wild-type mice $(n=11)$ and $12.8 \pm 3.6 \mathrm{pA}$ in the Fmrl ko mice $(n=8)$ (Fig. $6 D)$. These values were significantly lower than in nontrimmed mice ( $\sim 65 \%$ of control; $p<0.05$ ). Therefore, whisker trimming induced a depression of $\mathrm{L} 4 \rightarrow \mathrm{L} 3$ synapses in both wild-type and Fmr1 ko mice. A compensatory increase in the connection probability could explain the lack of experiencedependent depression at the $\mathrm{L} 4 \rightarrow \mathrm{L} 3$ projections in the Fmrl ko mice (Fig. 5C). Our data imply that deprivation and lack of FMRP cause a reduction in the strength of the $\mathrm{L} 4 \rightarrow \mathrm{L} 3$ projection through distinct synaptic mechanisms.

\section{Developmentally transient circuit phenotypes in Fmr1 ko mice}

Mental retardation syndromes are often associated with developmental delays (Guerrini et al., 2003; Wiesner et al., 2004; Ess, 2006). We therefore tested whether the somatosensory circuit phenotypes in Fmrl ko mice persisted throughout development. Input maps measured in Fmr1 ko and wild-type mice at the end of the third postnatal week (P19-P22) were comparable (Fig. 7A). The difference in synaptic input originating from L4 barrels between the wild-type mice and the Fmrl ko mice was reduced and not significant (wild type, $5.2 \pm 0.5 \mathrm{pA}, n=18$; Fmr 1 ko, $4.3 \pm 0.6$ pA, $n=13$; NS) (Fig. 7B).

We also reconstructed the axonal arbors of L4 cells (P20P22) (Fig. 7C). The total axonal length density in $\mathrm{L} 2 / 3$ was identical in wild-type and Fmr1 ko mice (wild type, $6.9 \pm 0.8$ $\mathrm{mm}, n=14$; Fmr1 ko, $6.7 \pm 0.9 \mathrm{~mm}, n=11$ ). In contrast to the younger age, the spatial distribution of axons in L2/3 was not different (Fig. 7D) (mean lateral distance; wild type, $132 \pm 8$ $\mu \mathrm{m}$; Fmrl ko, $148 \pm 15 \mu \mathrm{m}$; NS). Comparing the spatial distribution of L4 cell axon arbors in the Fmr1 ko mice across age groups suggests that the loss of the axon phenotype is attributable to axon addition selectively above the cell somata with age (supplemental Fig. 4, available at www.jneurosci.org as supplemental material).

\section{Discussion}

We compared the development of ascending excitatory projections in the barrel cortex of the wild-type and Fmr1 ko mice. We found multiple independent phenotypes in the $\mathrm{L} 4 \rightarrow \mathrm{L} 3$ projection of Fmr1 ko mice. This synaptic projection was weak and morphologically diffuse and displayed altered experiencedependent plasticity.

\section{Multiple, mechanistically independent defects in the} $\mathrm{L} 4 \rightarrow \mathrm{L} 3$ projections

We mapped the ascending excitatory circuits impinging onto L3 neurons in the barrel cortex of developing Fmr1 ko mice. The major features of the circuits were similar in wild-type and Fmr1 ko mice. $\mathrm{L} 3$ neurons received strong excitatory input from L4 and weaker input from L5A and L5B. The circuits were mostly contained in single barrel columns. Thus, FMRP does not prevent the development of the normal columnar organization of functional cortical circuits. However, we observed three independent phenotypes of the ascending circuits (Fig. 8). First, the strength of the 
A

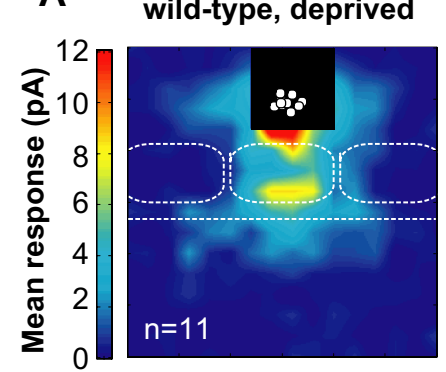

B

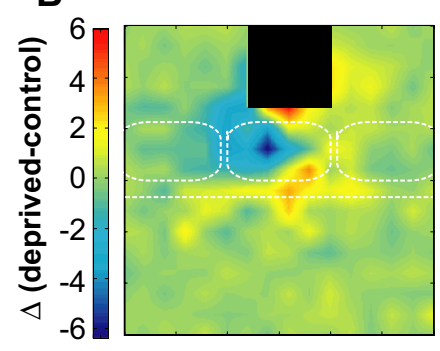

Fmr1 ko, deprived

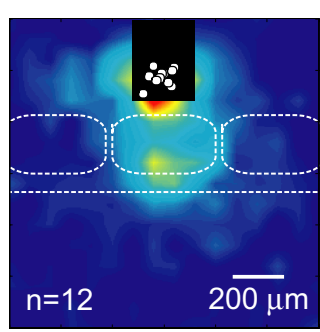

L4

L5A
C

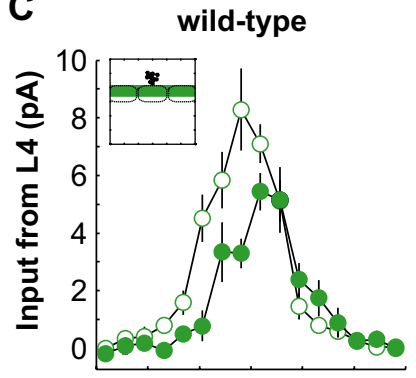

D

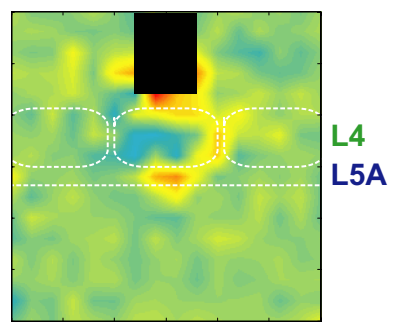

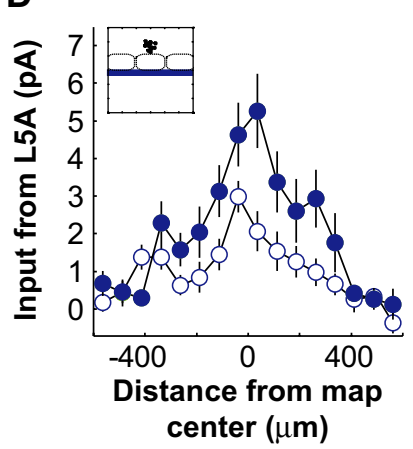

Fmr1 ko
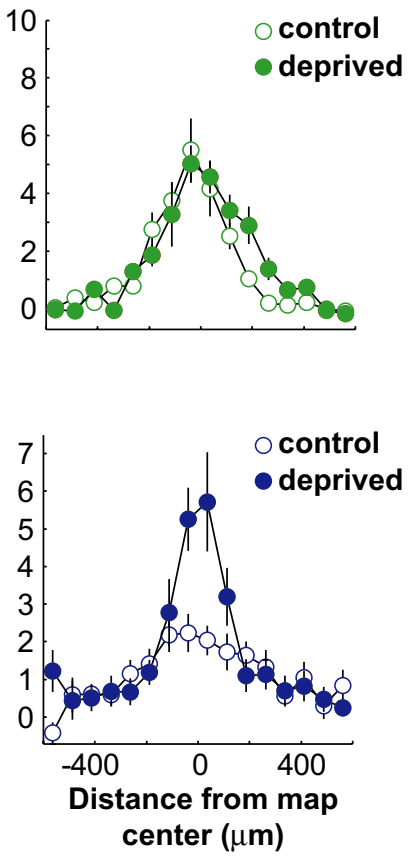

Figure 5. Experience-dependent plasticity is blocked at selected intracortical projections in $F m r 1$ ko mice. $A$, Averaged synaptic input maps from L 3 cells for sensory deprived wild-type (left) and Fmr1 ko (right) mice. The horizontal dashed line is the L5A/L5B boundary. B, Difference map was made by subtracting the averaged control from the deprived map for wild-type (left) and Fmr $1 \mathrm{ko}$ (right) mice. C, Horizontal profile of L4 synaptic input in control condition (open symbol) and after sensory deprivation (close symbol) in wild-type mice (left) and Fmr 1 ko (right) mice. $\boldsymbol{D}$, Same as in C for L5A synaptic input. Error bars indicate SEM.

$\mathrm{L} 4 \rightarrow \mathrm{L} 3$ projection, but not the $\mathrm{L} 5 \mathrm{~A} \rightarrow \mathrm{L} 3$ or $\mathrm{L} 5 \mathrm{~B} \rightarrow \mathrm{L} 3$ projections, was decreased by $40 \%$ in the Fmrl ko mice. This defect was likely caused by a reduction in the connection probability between L4 stellate cells and L3 pyramidal cells. The strength of the connection between coupled pairs was normal. This reduction in the number of functional connections could be accompanied by spine defects (e.g., thin spines) (Comery et al., 1997; Irwin et al., 2000; Nimchinsky et al., 2001; McKinney et al., 2005) and a concomitant increase of silent synapses.

We note that our measurements do not exclude the possibility of concomitant changes in inhibitory circuits (El Idrissi et al., 2005; D'Hulst et al., 2006; Selby et al., 2007) in Fmr1 ko mice. However, these changes would not affect our measurement of L4 $\rightarrow$ L3 projection for three reasons: (1) the synaptic responses were recorded at the reversal potential of inhibitory currents, (2) L3 interneurons were not excited by photostimulations in L4 (see Materials and Methods), and (3) the photoexcitability of L4 cells was similar in Fmr1 ko and wild-type mice (Fig. $2 F$ ). Furthermore, we did not investigate possible relationships between the defects in the L4 $\rightarrow$ L3 projection in Fmr1 ko mice and the well known augmentation in metabotropic glutamate receptor (mGluR)-mediated LTD (Huber et al., 2002; Koekkoek et al., 2003). Excessive mGluR signaling may have contributed to developmental mechanisms leading to this Fmr1 map phenotype (Dolen et al., 2007). However, direct activation of mGluRs during the experiment did not alter our measurements because plasticity was not induced during LSPS mapping (see Materials and Methods) (supplemental Fig. 2D, available at www.jneurosci.org as supplemental material).

Findings from other groups also indicate lower connection probabilities in Fmrl ko mice based on studies in a variety of systems, including cultured hippocampal neurons (Braun and Segal, 2000; Antar et al., 2006; Hanson and Madison, 2007) and climbing fiber to Purkinje cell synapses (Koekkoek et al., 2005). A recent study suggests a presynaptic role of FMRP (Hanson and Madison, 2007). In contrast, acute expression of FMRP in hippocampal neurons from Fmr1 ko mice reduced excitatory transmission from the postsynaptic site through a decrease of the number of synaptic contacts per connection (Pfeiffer and Huber, 2007). These observations suggest that FMRP regulates the formation and/or stabilization of neuronal connections through multiple presynaptic and postsynaptic mechanisms.

Second, L4 axons were abnormally diffuse in the L2/3 of young Fmr1 ko mice. Thus, FMRP plays a role in axon guidance or axon pruning in the neocortex. These findings are consistent with previous studies of developing axons in cultured hippocampal neurons (Antar et al., 2006) and the mushroom body in Drosophila (Michel et al., 2004). However, computation of the geometric input (Lubke et al., 2003; Shepherd et al., 2005) showed that these diffuse axons by themselves can account for at most $8 \%$ of the total reduction in the strength of the $\mathrm{L} 4 \rightarrow \mathrm{L} 3$ projection. Thus, the diffuse axon arbors and the weak $\mathrm{L} 4 \rightarrow \mathrm{L} 3$ projection are independent phenotypes of Fmrl ko mice.

Third, the L4 $\rightarrow$ L3 projection did not show experiencedependent depression in Fmr1 ko mice. Because the L4 $\rightarrow$ L3 projection is weak in Fmrl ko mice with normal experience, it could be that, in Fmrl ko mice, the L4 $\rightarrow$ L3 projection could already be depressed, occluding additional depression (Allen et al., 2003). However, synaptic currents recorded from individual L4 $\rightarrow$ L3 connections had similar amplitudes in both genotypes with normal experience, and they decreased in both genotypes after sensory deprivation. This suggests that the apparent loss of plasticity in the Fmrl ko mice is attributable to a remarkable balance between synaptic depression and a compensatory increase in intracortical connectivity. 
A

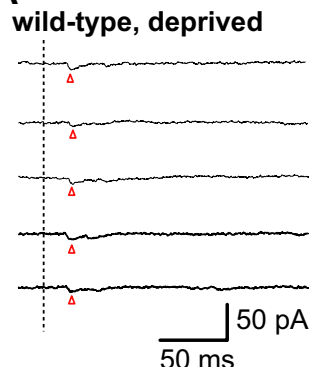

Fmr1 ko, deprived

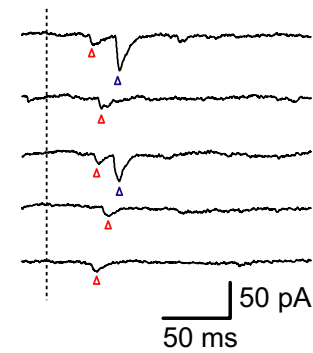

D

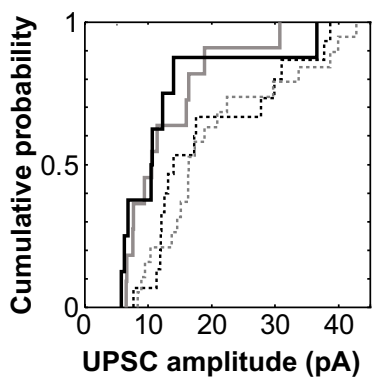

Figure 6. Sensory deprivation depresses the $L 4 / L 3$ synapses in wild-type and $F m r 1$ ko mice. $A$, Example of $L 3$ responses evoked by the minimal photostimulation of a single $L 4$ cell in a deprived wild-type (top) and a deprived $F m r 1$ ko (bottom) animal. The arrowheads indicate UPSCs evoked by the stimulation of distinct presynaptic $L 4$ cells (one color per presynaptic cell). $\boldsymbol{B}$, Amplitude of UPSCs evoked in a deprived wild-type (top) and deprived $F m r 1 \mathrm{ko}$ (bottom) animal as a function of latency. Clusters of UPSCS are shown in blue and red. Spontaneous EPSCs are shown in black. The cells are the same as in A. C, Histogram of amplitude for clusters of UPSCs (red and blue) evoked in a wild-type (top) and $F m r 1 \mathrm{ko}$ (bottom) animal. Noise amplitude is shown in gray. The cells are the same as in $\boldsymbol{A}$ and $\boldsymbol{B}$. D, Cumulative distribution of UPSC mean amplitudes in wild-type (gray) and Fmr $1 \mathrm{ko}$ (black) mice in control conditions (dashed lines) and after sensory deprivation (solid lines).

\section{Defects in specific excitatory projections}

LSPS allowed us to survey multiple excitatory projections impinging onto L3 cells, including excitation arising from L4, L5A, and L5B cells. The circuit defects in Fmrl ko mice were specific to $\mathrm{L} 4 \rightarrow \mathrm{L} 3$ projections in barrel columns. Whereas $\mathrm{L} 4 \rightarrow \mathrm{L} 3$ projections were weaker in the Fmr1 ko mice, L5A $\rightarrow \mathrm{L} 3$ and $\mathrm{L} 5 \mathrm{~B} \rightarrow \mathrm{L} 3$ projections were unchanged [although $\mathrm{L} 5 \mathrm{~B} \rightarrow \mathrm{L} 3$ projections were weaker in septal columns (supplemental Fig. 1, available at www.jneurosci.org as supplemental material)]. Similarly, whereas the experience-dependent depression at the L4 $\rightarrow$ L3 projection was abolished, the experience-dependent potentiation in the $\mathrm{L} 5 \mathrm{~A} \rightarrow \mathrm{L} 3$ projection was partially maintained in Fmr1 ko mice. These findings are compatible with the notion of multiple plasticity mechanisms regulating circuit development and reorganization in the somatosensory cortex (Foeller and Feldman, 2004; Feldman and Brecht, 2005). Our study highlights the importance of analyzing complex neuronal phenotypes in multiple specific circuits.

The spatial distribution of $\mathrm{L} 5 \mathrm{~A} \rightarrow \mathrm{L} 3$ projections strengthened by sensory deprivation was different in Fmrl ko mice. The mech- anism underlying this strengthening is unknown but could involve LTP. In Fmr1 ko mice, LTP is blocked in cortex ( $\mathrm{Li}$ et al., 2002; Larson et al., 2005; Zhao et al., 2005; Desai et al., 2006; Wilson and Cox, 2007) and in the amygdala (Zhao et al., 2005), but preserved in the hippocampus (Godfraind et al., 1996; Li et al., 2002; Larson et al., 2005). The complex phenotype of the $\mathrm{L} 5 \mathrm{~A} \rightarrow \mathrm{L} 3$ plasticity suggests heterogeneous mechanisms or a cell-specific expression of FMRP in these projections.

The normal sensory-induced depression at individual $\mathrm{L} 4 \rightarrow \mathrm{L} 3$ connections in Fmr1 ko mice contrasts with the enhancement of LTD observed in the hippocampus (Huber et al., 2002) and cerebellum (Koekkoek et al., 2003) in these mice. Like CA1 LTD (Kemp and Bashir, 1999; Huber et al., 2000), the cortical L4 $\rightarrow$ L3 LTD requires the activation of group 1 mGluRs (V.A. Bender et al., 2006), a proposed therapeutic target for fragile $\mathrm{X}$ syndrome (Bear et al., 2004). However, the two LTDs differ because L4 $\rightarrow$ L3 LTD has a presynaptic locus of expression, it depends on a retrograde endocannabinoid signaling (V. A. Bender et al., 2006; Crozier et al., 2007), and it is likely independent of de novo protein synthesis (Desai et al., 2006). This difference of mechanisms could explain the lack of enhancement of the sensoryinduced depression at L4 $\rightarrow$ L3 synapses in the barrel cortex of Fmrl ko mice. Our results imply that using mGluR antagonists as pharmacological treatment will have different effects in different brain regions.

\section{Circuit defects in Fmr1 ko mice are developmentally transient}

Both the connection probability between L4 and L3 neurons and the shapes of L4 cell axons in Fmr1 ko mice became indistinguishable from wild-type mice by the third postnatal week. Other phenotypes of Fmr1 ko mice are also developmentally transient. For example, L5 pyramidal cells in the barrel cortex have longer and denser spines in neonates but not in 4-week-old mice (Nimchinsky et al., 2001; Galvez and Greenough, 2005). The developmental decline of Fmr1 ko phenotypes could reflect a developmental switch in mechanisms (Yasuda et al., 2003; Bannister et al., 2005; Nosyreva and Huber, 2005), or a developmental regulation of FMRP in wild-type animals (Bakker et al., 2000; Wang et al., 2004), or a developmental upregulation of FXR1P and FXR2P in Fmr1 ko mice (Bakker et al., 2000). Alternatively, the absence of FMRP could simply slow development.

These defects coincide with the critical period of the L4 $\rightarrow$ L3 projection in the barrel cortex (Fox, 1992; Micheva and Beaulieu, 1996; Lendvai et al., 2000; Stern et al., 2001; Shepherd et al., 2003; K. J. Bender et al., 2006) and possibly with critical periods in downstream circuits. During this time, the cortex of Fmrl ko mice is deprived from normal sensory input relayed through L4 barrels. As a consequence, the structured activity driving experience-dependent development throughout the brain may 
be perturbed. Additional studies are needed to test whether developmentally transient circuit defects in the barrel cortex of Fmrl ko mice have long-lasting effects on other cortical circuits.

\section{References}

Allen CB, Celikel T, Feldman DE (2003) Longterm depression induced by sensory deprivation during cortical map plasticity in vivo. Nat Neurosci 6:291-299.

Antar LN, Li C, Zhang H, Carroll RC, Bassell GJ (2006) Local functions for FMRP in axon growth cone motility and activity-dependent regulation of filopodia and spine synapses. $\mathrm{Mol}$ Cell Neurosci 32:37-48.

Ashley Jr CT, Wilkinson KD, Reines D, Warren ST (1993) FMR1 protein: conserved RNP family domains and selective RNA binding. Science 262:563-566.

Bakker CE, de Diego Otero Y, Bontekoe C, Raghoe P, Luteijn T, Hoogeveen AT, Oostra BA, Willemsen R (2000) Immunocytochemical and biochemical characterization of FMRP, FXR1P, and FXR2P in the mouse. Exp Cell Res 258:162-170.

Bannister NJ, Benke TA, Mellor J, Scott H, Gurdal E, Crabtree JW, Isaac JT (2005) Developmental changes in AMPA and kainate receptormediated quantal transmission at thalamocortical synapses in the barrel cortex. J Neurosci 25:5259-5271.

Bear MF, Huber KM, Warren ST (2004) The mGluR theory of fragile X mental retardation. Trends Neurosci 27:370-377.

Bender KJ, Rangel J, Feldman DE (2003) Development of columnar topography in the excitatory layer 4 to layer $2 / 3$ projection in rat barrel cortex. J Neurosci 23:8759-8770.

Bender KJ, Allen CB, Bender VA, Feldman DE (2006) Synaptic basis for whisker deprivation-induced synaptic depression in rat somatosensory cortex. J Neurosci 26:4155-4165.

Bender VA, Bender KJ, Brasier DJ, Feldman DE (2006) Two coincidence detectors for spike timing-dependent plasticity in somatosensory cortex. J Neurosci 26:4166-4177.

Bernardo KL, Woolsey TA (1987) Axonal trajectories between mouse somatosensory thalamus and cortex. J Comp Neurol 258:542-564.

Braun K, Segal M (2000) FMRP involvement in formation of synapses among cultured hippocampal neurons. Cereb Cortex 10:1045-1052.

Brown V, Jin P, Ceman S, Darnell JC, O'Donnell WT, Tenenbaum SA, Jin X, Feng Y, Wilkinson KD, Keene JD, Darnell RB, Warren ST (2001) Microarray identification of FMRP-associated brain mRNAs and altered mRNA translational profiles in fragile X syndrome. Cell 107:477-487.

Bureau I, Shepherd GM, Svoboda K (2004) Precise development of functional and anatomical columns in the neocortex. Neuron 42:789-801.

Bureau I, von Saint Paul F, Svoboda K (2006) Interdigitated paralemniscal and lemniscal pathways in the mouse barrel cortex. PLoS Biol 4:e382.

Canepari M, Nelson L, Papageorgiou G, Corrie JE, Ogden D (2001) Photochemical and pharmacological evaluation of 7-nitroindolinyl-and 4-methoxy-7-nitroindolinyl-amino acids as novel, fast caged neurotransmitters. J Neurosci Methods 112:29-42.

Chen L, Toth M (2001) Fragile X mice develop sensory hyperreactivity to auditory stimuli. Neuroscience 103:1043-1050.

Comery TA, Harris JB, Willems PJ, Oostra BA, Irwin SA, Weiler IJ, Greenough WT (1997) Abnormal dendritic spines in fragile X knockout mice: maturation and pruning deficits. Proc Natl Acad Sci USA 94:5401-5404.

Crozier RA, Wang Y, Liu CH, Bear MF (2007) Deprivation-induced synaptic depression by distinct mechanisms in different layers of mouse visual cortex. Proc Natl Acad Sci USA 104:1383-1388.

Darnell JC, Fraser CE, Mostovetsky O, Stefani G, Jones TA, Eddy SR, Darnell RB (2005) Kissing complex RNAs mediate interaction between the
B

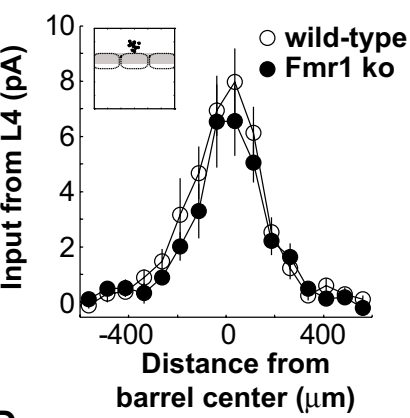

Fmr1 ko
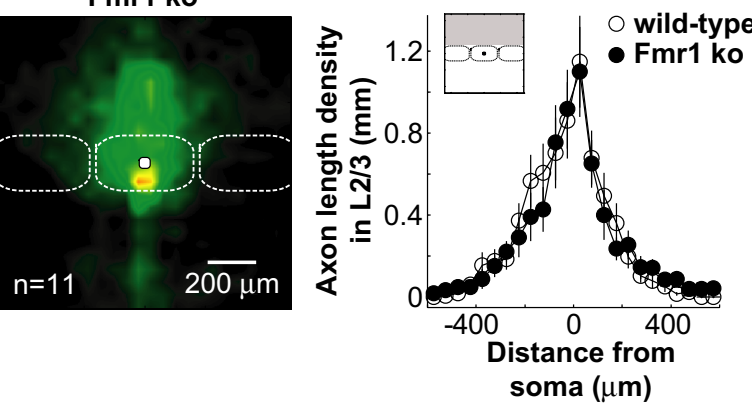
D'Hulst C, De Geest N, Reeve SP, Van Dam D, De Deyn PP, Hassan BA, Kooy RF (2006) Decreased expression of the GABAA receptor in fragile $X$ syndrome. Brain Res 1121:238-245.

Dolen G, Osterweil E, Rao BS, Smith GB, Auerbach BD, Chattarji S, Bear MF (2007) Correction of fragile X syndrome in mice. Neuron 56:955-962.

Dutch-Belgian Fragile X Consortium (1994) Fmrl knockout mice: a model to study fragile X mental retardation. Cell 78:23-33.

El Idrissi A, Ding XH, Scalia J, Trenkner E, Brown WT, Dobkin C (2005) Decreased GABA(A) receptor expression in the seizure-prone fragile $\mathrm{X}$ mouse. Neurosci Lett 377:141-146.

Ess KC (2006) The neurobiology of tuberous sclerosis complex. Semin Pediatr Neurol 13:37-42.

Feldman DE, Brecht M (2005) Map plasticity in somatosensory cortex. Science 310:810-815.

Feldmeyer D, Lubke J, Silver RA, Sakmann B (2002) Synaptic connections between layer 4 spiny neurone-layer $2 / 3$ pyramidal cell pairs in juvenile rat barrel cortex: physiology and anatomy of interlaminar signalling within a cortical column. J Physiol (Lond) 538:803-822.

Feng Y, Absher D, Eberhart DE, Brown V, Malter HE, Warren ST (1997) FMRP associates with polyribosomes as an mRNP, and the I304N mutation of severe fragile $\mathrm{X}$ syndrome abolishes this association. Mol Cell 1:109-118.

Finnerty GT, Roberts LS, Connors BW (1999) Sensory experience modifies the short-term dynamics of neocortical synapses. Nature 400:367-371.

Foeller E, Feldman DE (2004) Synaptic basis for developmental plasticity in somatosensory cortex. Curr Opin Neurobiol 14:89-95.

Fox K (1992) A critical period for experience-dependent synaptic plasticity in rat barrel cortex. J Neurosci 12:1826-1838.

Galvez R, Greenough WT (2005) Sequence of abnormal dendritic spine development in primary somatosensory cortex of a mouse model of the fragile X mental retardation syndrome. Am J Med Genet A 135:155-160.

Godfraind JM, Reyniers E, De Boulle K, D’Hooge R, De Deyn PP, Bakker CE, Oostra BA, Kooy RF, Willems PJ (1996) Long-term potentiation in the hippocampus of fragile X knockout mice. Am J Med Genet 64:246-251.

Greenough WT, Klintsova AY, Irwin SA, Galvez R, Bates KE, Weiler IJ (2001) Synaptic regulation of protein synthesis and the fragile $\mathrm{X}$ protein. Proc Natl Acad Sci USA 98:7101-7106.

Grossman AW, Elisseou NM, McKinney BC, Greenough WT (2006) Hippocampal pyramidal cells in adult Fmrl knockout mice exhibit an immature-appearing profile of dendritic spines. Brain Res 1084:158-164.

Guerrini R, Carrozzo R, Rinaldi R, Bonanni P (2003) Angelman syndrome: etiology, clinical features, diagnosis, and management of symptoms. Paediatr Drugs 5:647-661.

Hanson JE, Madison DV (2007) Presynaptic Fmr1 genotype influences the degree of synaptic connectivity in a mosaic mouse model of fragile $\mathrm{X}$ syndrome. J Neurosci 27:4014-4018.

Huber KM, Kayser MS, Bear MF (2000) Role for rapid dendritic protein synthesis in hippocampal mGluR-dependent long-term depression. Science 288:1254-1257.

Huber KM, Gallagher SM, Warren ST, Bear MF (2002) Altered synaptic plasticity in a mouse model of fragile X mental retardation. Proc Natl Acad Sci USA 99:7746-7750.

Irwin SA, Galvez R, Greenough WT (2000) Dendritic spine structural anomalies in fragile-X mental retardation syndrome. Cereb Cortex 10:1038-1044.

Irwin SA, Patel B, Idupulapati M, Harris JB, Crisostomo RA, Larsen BP, Kooy F, Willems PJ, Cras P, Kozlowski PB, Swain RA, Weiler IJ, Greenough WT (2001) Abnormal dendritic spine characteristics in the temporal and visual cortices of patients with fragile-X syndrome: a quantitative examination. Am J Med Genet 98:161-167.

Jin P, Warren ST (2000) Understanding the molecular basis of fragile X syndrome. Hum Mol Genet 9:901-908.

Kemp N, Bashir ZI (1999) Induction of LTD in the adult hippocampus by the synaptic activation of AMPA/kainate and metabotropic glutamate receptors. Neuropharmacology 38:495-504.

Koekkoek SK, Hulscher HC, Dortland BR, Hensbroek RA, Elgersma Y, Ruigrok TJ, De Zeeuw CI (2003) Cerebellar LTD and learningdependent timing of conditioned eyelid responses. Science 301:1736-1739.

Koekkoek SK, Yamaguchi K, Milojkovic BA, Dortland BR, Ruigrok TJ, Maex R, De Graaf W, Smit AE, Vanderwerf F, Bakker CE, Willemsen R, Ikeda T, Kakizawa S, Onodera K, Nelson DL, Mientjes E, Joosten M, De Schutter E,
Oostra BA, Ito M, et al. (2005) Deletion of FMR1 in Purkinje cells enhances parallel fiber LTD, enlarges spines, and attenuates cerebellar eyelid conditioning in fragile X syndrome. Neuron 47:339-352.

Larson J, Jessen RE, Kim D, Fine AK, du Hoffmann J (2005) Age-dependent and selective impairment of long-term potentiation in the anterior piriform cortex of mice lacking the fragile $\mathrm{X}$ mental retardation protein. J Neurosci 25:9460-9469.

Lendvai B, Stern E, Chen B, Svoboda K (2000) Experience-dependent plasticity of dendritic spines in the developing rat barrel cortex in vivo. Nature 404:876-881.

Li J, Pelletier MR, Perez Velazquez JL, Carlen PL (2002) Reduced cortical synaptic plasticity and GluR1 expression associated with fragile X mental retardation protein deficiency. Mol Cell Neurosci 19:138-151.

Lubke J, Roth A, Feldmeyer D, Sakmann B (2003) Morphometric analysis of the columnar innervation domain of neurons connecting layer 4 and layer 2/3 of juvenile rat barrel cortex. Cereb Cortex 13:1051-1063.

McKinney BC, Grossman AW, Elisseou NM, Greenough WT (2005) Dendritic spine abnormalities in the occipital cortex of C57BL/6 Fmr1 knockout mice. Am J Med Genet B Neuropsychiatr Genet 136:98-102.

Michel CI, Kraft R, Restifo LL (2004) Defective neuronal development in the mushroom bodies of Drosophila fragile X mental retardation $1 \mathrm{mu}$ tants. J Neurosci 24:5798-5809.

Micheva KD, Beaulieu C (1996) Quantitative aspects of synaptogenesis in the rat barrel field cortex with special reference to GABA circuitry. J Comp Neurol 373:340-354.

Mineur YS, Huynh LX, Crusio WE (2006) Social behavior deficits in the Fmrl mutant mouse. Behav Brain Res 168:172-175.

Mullen RJ, Buck CR, Smith AM (1992) NeuN, a neuronal specific nuclear protein in vertebrates. Development 116:201-211.

Musumeci SA, Bosco P, Calabrese G, Bakker C, De Sarro GB, Elia M, Ferri R, Oostra BA (2000) Audiogenic seizures susceptibility in transgenic mice with fragile X syndrome. Epilepsia 41:19-23.

Nimchinsky EA, Oberlander AM, Svoboda K (2001) Abnormal development of dendritic spines in FMR1 knock-out mice. J Neurosci 21:5139-5146.

Nosyreva ED, Huber KM (2005) Developmental switch in synaptic mechanisms of hippocampal metabotropic glutamate receptor-dependent longterm depression. J Neurosci 25:2992-3001.

O’Donnell WT, Warren ST (2002) A decade of molecular studies of fragile X syndrome. Annu Rev Neurosci 25:315-338.

Paradee W, Melikian HE, Rasmussen DL, Kenneson A, Conn PJ, Warren ST (1999) Fragile X mouse: strain effects of knockout phenotype and evidence suggesting deficient amygdala function. Neuroscience 94:185-192.

Peier AM, McIlwain KL, Kenneson A, Warren ST, Paylor R, Nelson DL (2000) (Over)correction of FMR1 deficiency with YAC transgenics: behavioral and physical features. Hum Mol Genet 9:1145-1159.

Pfeiffer BE, Huber KM (2007) Fragile X mental retardation protein induces synapse loss through acute postsynaptic translational regulation. J Neurosci 27:3120-3130.

Selby L, Zhang C, Sun QQ (2007) Major defects in neocortical GABAergic inhibitory circuits in mice lacking the fragile $\mathrm{X}$ mental retardation protein. Neurosci Lett 412:227-232.

Shepherd GM, Svoboda K (2005) Laminar and columnar organization of ascending excitatory projections to layer $2 / 3$ pyramidal neurons in rat barrel cortex. J Neurosci 25:5670.

Shepherd GM, Pologruto TA, Svoboda K (2003) Circuit analysis of experience-dependent plasticity in the developing rat barrel cortex. Neuron 38:277-289.

Shepherd GM, Stepanyants A, Bureau I, Chklovskii DB, Svoboda K (2005) Geometric and functional organization of cortical circuits. Nat Neurosci 8:782-790.

Silver RA, Lubke J, Sakmann B, Feldmeyer D (2003) High-probability uniquantal transmission at excitatory synapses in barrel cortex. Science 302:1981-1984.

Siomi H, Siomi MC, Nussbaum RL, Dreyfuss G (1993) The protein product of the fragile X gene, FMR1, has characteristics of an RNA-binding protein. Cell 74:291-298.

Siomi MC, Zhang Y, Siomi H, Dreyfuss G (1996) Specific sequences in the fragile $\mathrm{X}$ syndrome protein FMR1 and the FXR proteins mediate their binding to $60 \mathrm{~S}$ ribosomal subunits and the interactions among them. Mol Cell Biol 16:3825-3832.

Spencer CM, Alekseyenko O, Serysheva E, Yuva-Paylor LA, Paylor R (2005) 
Altered anxiety-related and social behaviors in the Fmr 1 knockout mouse model of fragile X syndrome. Genes Brain Behav 4:420-430.

Stern EA, Maravall M, Svoboda K (2001) Rapid development and plasticity of layer 2/3 maps in rat barrel cortex in vivo. Neuron 31:305-315.

Todd PK, Mack KJ, Malter JS (2003) The fragile X mental retardation protein is required for type-I metabotropic glutamate receptor-dependent translation of PSD-95. Proc Natl Acad Sci USA 100:14374-14378.

Wang H, Ku L, Osterhout DJ, Li W, Ahmadian A, Liang Z, Feng Y (2004) Developmentally-programmed FMRP expression in oligodendrocytes: a potential role of FMRP in regulating translation in oligodendroglia progenitors. Hum Mol Genet 13:79-89.

Wiesner GL, Cassidy SB, Grimes SJ, Matthews AL, Acheson LS (2004) Clinical consult: developmental delay/fragile X syndrome. Prim Care 31:621-625, x.

Wilson BM, Cox CL (2007) Absence of metabotropic glutamate receptormediated plasticity in the neocortex of fragile X mice. Proc Natl Acad Sci USA 104:2454-2459.
Woolsey TA, Van der Loos H (1970) The structural organization of layer IV in the somatosensory region (S1) of mouse cerebral cortex. Brain Res 17:205-242.

Yan QJ, Asafo-Adjei PK, Arnold HM, Brown RE, Bauchwitz RP (2004) A phenotypic and molecular characterization of the fmr1-tm1Cgr fragile $\mathrm{X}$ mouse. Genes Brain Behav 3:337-359.

Yasuda H, Barth AL, Stellwagen D, Malenka RC (2003) A developmental switch in the signaling cascades for LTP induction. Nat Neurosci 6:15-16.

Zhang YQ, Bailey AM, Matthies HJ, Renden RB, Smith MA, Speese SD, Rubin GM, Broadie K (2001) Drosophila fragile X-related gene regulates the MAP1B homolog Futsch to control synaptic structure and function. Cell 107:591-603.

Zhao MG, Toyoda H, Ko SW, Ding HK, Wu LJ, Zhuo M (2005) Deficits in trace fear memory and long-term potentiation in a mouse model for fragile X syndrome. J Neurosci 25:7385-7392. 